\title{
Student Motivation Associated With the Practice of Individual and Team Sports in Physical Education Classes
}

\author{
Ricardo Ferraz ${ }^{1,2 *}$, Miguel Silva ${ }^{1}$, Daniel A. Marinho ${ }^{1,2}$, Henrique P. Neiva ${ }^{1,2}$, Luís Branquinho ${ }^{1}$ \\ ${ }^{1}$ Department of Sport Sciences, University of Beira Interior, 6201-001 Covilhã, Portugal \\ ${ }^{2}$ Research Center in Sports Sciences, Health Sciences and Human Development (CIDESD), 6201-001 Covilhã, Portugal
}

DOI: $10.36348 /$ jaspe.2021.v04i04.002

| Received: 16.02.2021 | Accepted: 27.02.2021 | Published: 05.04.2021

*Corresponding author: Ricardo Ferraz

\section{Abstract}

Physical education teachers face the challenge of providing motivating and enjoyable experiences during physical education classes on a daily basis. Thus, the level of students' motivation for physical education takes on special importance. The main objective of this work was to establish the motivations of students of regular and professional education regarding the practice of collective or individual modalities in physical education classes. Fifty-one students participated in the study ( 36 men and 15 women; mean age $=15.67 \pm 1.0$ ). The sample was divided into two classes; one of regular education and another of professional education. The students answered a questionnaire that aimed to verify their motivations regarding the preference of individual or team sports during physical education class. The results show a clear preference for the practice of team sports, compared to individual sports, regardless of the type of student education. It was concluded that, both regular and professional education students were more motivated to practice team sports during physical education. In addition, the results show a greater predominance in the teaching of team sports during physical education classes.

Keywords: School, physical education, motivation, individual sports, team sports.

Copyright () 2021 The Author(s): This is an open-access article distributed under the terms of the Creative Commons Attribution 4.0 International License (CC BY-NC 4.0) which permits unrestricted use, distribution, and reproduction in any medium for non-commercial use provided the original author and source are credited.

\section{INTRODUCTION}

Physical education is undoubtedly linked to physical activity, which has been previously defined as any form of physical exercise that involves the body in motion [1]. Physical education plays a fundamental role in the integral development of the student, enabling cognitive, psychomotor and affective development, while stimulating healthy lifestyles, socialization, team spirit and sports practice [2, 3]. In fact, the benefits of physical education classes are numerous, including improvements in cardiovascular and respiratory function, decreased levels of anxiety and depression, increased sense of well-being, development of cognitive and social valences and academic achievement [4-7]. This line of thought has been studied previously [2], who found significant contributions to the education and development of children and young people in five domains - physical, lifestyle, affective, social and cognitive. The assumed importance of this discipline is also reflected in the fact that it is the only opportunity that many children / young people have to practice physical activity, and to learn new motor skills and modalities they have never practiced before [8, 9]. For students to perform the activities proposed in class, it is imperative that they feel motivated, because motivation leads to a better understanding of learning and performance of motor skills [10].

The concept of motivation has been previously defined as a process that guides all types of human activity, through intrinsic and / or extrinsic factors, which guarantees the individual the quality of persistence and directs attention to the development of the most diverse activities [11]. Motivation is considered a fundamental element for the practice of physical activity, and the theory of self-determination is one of the most used structures to understand this phenomenon [12]. In the theory of self-determination [13], three types of motivation are numbered: intrinsic, extrinsic and one motivation, which correspond to five types of behavioural regulations that are placed along a continuum that varies from high to low selfdetermination. However, intrinsic motivation represents the highest degree of self-determined motivation. 
Ricardo Ferraz et al., J Adv Sport Phys Edu, Apr, 2021; 4(4): 51-58

New generations have been considered to be particularly difficult to motivate when traditional teaching methods are applied [14]. Therefore, the study of motivation is important to understand the reasons that lead students to perform certain tasks with greater or lesser dedication [15]. Thus, there is a clear potential link between motivation and learning, characterized as the determining factors for the success and performance of students in physical education. In fact, motivational and emotional variables play a crucial, if not the most crucial, role in academic success [16, 17]. In this regard, motivational factors can be decisive for the commitment with which tasks are carried out, as well carrying out certain activities over a long period of time [18]. Therefore, it can be concluded that the praise of a teacher can boost a student's motivation to practice a certain type of exercise, thus enhancing learning [19].

Combining these two aspects (i.e., physical education and motivation), reveals the reasons that lead to practice. In this respect, According to a previously investigation [20], the reasons for students' involvement in sports vary based on certain factors, among which are joy; the improvement of skills; learning new skills; practice with friends; the acquisition of physical form; and the feeling of pleasure in a particular sport. Thus, it is essential to understand the reasons that lead students to feel motivated for a given activity, given that knowledge about the motivating elements can play a fundamental role in the planning of classes, helping to meet the students' interests [21]. In addition to the reasons mentioned above, another study [22] also mentions that there may be several explanations that can be related to these manifestations and induce changes in people's behaviour regarding motivation, such as impulses, needs, beliefs, values, fears, goals, social pressure, self-confidence, interests, curiosities, incentives and expectations. These vary from person to person, based on their individual characteristics. It is therefore important to realize that the impact of the degree of motivation can interfere with students' choices. Furthermore, students with a higher level of motivation are able to achieve better results, and consequently tend to achieve higher levels of satisfaction compared to students with a lower motivation to practice any sport.

It is therefore pertinent to investigate students' motivation according to the type of sport (i.e., individual or collective) taught in physical education classes. In this regard, to the best of the authors' knowledge, only a few studies have been conducted on this topic [23-26]. In one of these studies [23], concluded that students' preference for a particular modality for which they felt a greater motivation was not random and was not only related to interests but also to the need for self-realisation; however, a previously study [24] found that behind this choice there was something conscious or unconscious that guided this option. In fact, the same study also mentioned that some motivating or demotivating factors concerned the content covered in class, mainly the choice of the modalities that were practiced. In this regard, a study [25] reported that students who already practiced modalities outside the school context ended up practicing it with greater motivation in physical education classes, not least because in most cases they were better than their colleagues. One of the factors for the motivation or lack of it in some modalities was the systematic repetition of them throughout the years of schooling, the students lacking the opportunity to practice other modalities for which they could feel more motivated [26].

Therefore, considering the aforementioned, it is important to continue to investigate students' motivations in relation to the preference between team and individual sports in the school context. Thus, the main aim of this work was to investigate students' motivations for the practice of collective / individual sports during physical education class. In addition, the aim was to compare the motivational level by gender (male and female) and by type of education (regular and professional), as well as to compare the motivational levels regarding the reasons why the students developed their preferences.

\section{MATERIAL AND METHODS}

A group of 51 students from a Portuguese school, (36 male and 15 female; mean age $=15.67 \pm$ 1.0) participated in the study. The sample was divided into two: a regular education (i.e., the most common type of education) a professional education class (i.e., the type of education where students learn specifically about an area where they want to professionalize). The regular education class consisted of 26 students (13 male and 13 female; age $=16.07 \pm 0.615$ ), whereas the professional education class consisted of 25 students (23 male and 2 female; age $=15.4 \pm 0.632$ )

All participants and the teacher were fully informed verbally and in writing regarding the nature of the study. They were informed that they could withdraw from the study at any time, even after giving their written consent. All parents provided their informed consent, for their children to participate in the study, which had the approval of the Academy's Ethical Advisory Commission and was conducted in accordance with the Declaration of Helsinki.

\section{Experimental Design}

This study aimed to identify the motivations of students regarding the preferences of individual or team sports in physical education classes. A questionnaire was provided at the end of a physical education class. All experimental procedures were performed in coordination with the teacher and did not cause any change in the students' routine. 
Ricardo Ferraz et al., J Adv Sport Phys Edu, Apr, 2021; 4(4): 51-58

\section{Procedures}

The instrument used was an adaptation of the questionnaire survey, developed and validated by Kobalt [27]. The questionnaire consisted of 4 multiplechoice questions, 1 open-ended question, and 2 questions in which each statement is answered on a Likert scale. The verification of the motivation trends for individual sports or team sports was achieved through descriptive statistical analysis. Thus, a frequency table was prepared considering the agreement or disagreement for each of the 4 multiple choice questions, the answer to the open question, and the 2 questions in which each statement is answered using a Likert scale of alternatives, in which the students indicate the extent to which they agree with the statements of the questionnaire items, the options being 'Agree', 'I'm in doubt' and 'Disagree'. In these two questions, each student only answered one depending on the answer to the question 'In Physical Education classes I feel more motivated when?'. If the student's answer was 'Team sports are addressed', then they were directed to only answer question 3, whereas if the answer was 'Individual sports are addressed', they were directed to only answer question 4. Before applying the questionnaire, students were informed that they could only answer questions with a single answer, and that they should answer according to what they were doing in their physical education classes and what they would like to do.

\section{Statistical Analysis}

The verification of the trends of motivation was done through descriptive statistical analysis. Thus, the table of frequencies was prepared considering the agreement or disagreement for each of the statements. The questionnaires results were grouped and processed so the respondents' responses could be analysed. The absolute and relative frequencies of the students' answers in each of the questions of the applied survey were the analysed. Fisher's exact test was used to compare 2 groups of independent samples, in order to test whether the variables were independent. Cramer's V was used to quantify the association between variables. The degree of association was classified based on the following criteria: $0<\mathrm{V}<0.1$ : very weak association; $0.1 \leq \mathrm{V}<0.3$ : weak association; $0.3 \leq \mathrm{V}<0.5$ : moderate association; and $V \geq 0.5$ : strong association [28]. Due to the characteristics of the sample, a p-value of 0.01 was used.

\section{RESULTS}

Table-1 shows the results for the question 'In Physical Education classes, I feel more motivated when?'. In this regard, a total of 48 students answered 'when team sports are approached' and only 3 students 'when individual sports are approached', which showed an evident preference for team sports.

Table-1: Values of relative and absolute frequencies of the answers on the motivation of students in physical education for collective and individual sports, by education type and gender

\begin{tabular}{|c|c|c|c|c|}
\hline & \multicolumn{2}{|c|}{ Type of Education } & \multicolumn{2}{|l|}{ Gender } \\
\hline & Regular & Professional & Male & Female \\
\hline Team sports are addressed & $24(47.1 \%)$ & $24(47.1 \%)$ & $34(66.7 \%)$ & $14(27.5 \%)$ \\
\hline Individual sports are addressed & $2(3.9 \%)$ & $1(1.9 \%)$ & $2(3.9 \%)$ & $1(1.9 \%)$ \\
\hline Total & $26(51 \%)$ & $25(49 \%)$ & $36(70.6 \%)$ & $15(29.4 \%)$ \\
\hline
\end{tabular}

Table-2 shows that of the total of respondents, 17 students did not practice any modality, 26 practiced a collective modality and 8 practiced an individual modality.

Table-2: Values of relative and absolute frequencies of the answers regarding whether or not students practice sport inside or outside the school context

\begin{tabular}{|l|l|l|l|l|}
\hline \multirow{2}{*}{} & \multicolumn{2}{|l|}{ Type of Education } & \multicolumn{2}{l|}{ Gender } \\
\cline { 2 - 5 } & Regular & Professional & Male & Female \\
\hline Do not. & $12(70.9 \%)$ & $5(29.4 \%)$ & $9(52.9 \%)$ & $8(47.1 \%)$ \\
\hline Yes, I play a team sport. & $8(30.8 \%)$ & $18(69.2 \%)$ & $21(80.8 \%)$ & $5(19.2 \%)$ \\
\hline Yes, I practice an individual sport. & $7(87.5 \%)$ & $1(12.5 \%)$ & $6(75 \%)$ & $2(25 \%)$ \\
\hline
\end{tabular}

When relating students who practiced modalities inside or outside the school context with the modalities in which they felt more motivated to practice in physical education, Table-3 indicates that 17 students did not practice any modality and were more motivated to practice modalities in physical education, and 26 students who practiced a collective modality felt more motivated to practice collective modality in physical education, whereas 5 of the students who practiced an individual modality were more motivated when approaching team sports in physical education and only 3 of them were motivated when individual sports were approached. 
Ricardo Ferraz et al., J Adv Sport Phys Edu, Apr, 2021; 4(4): 51-58

Table-3: Values on the relationship between students who practice modalities inside or outside the school context with the sport in which they feel most motivated in physical education classes.

\begin{tabular}{|l|l|l|l|}
\hline \multicolumn{2}{|c|}{ Team sports } & Individual sports \\
\hline \multirow{2}{*}{$\begin{array}{l}\text { Do you practice sports inside or outside the } \\
\text { school context? }\end{array}$} & Do not. & 17 & 0 \\
\cline { 2 - 4 } & Yes, team sport. & 26 & 0 \\
\cline { 2 - 4 } & Yes, individual sport. & 5 & 3 \\
\hline & Total & 48 & 3 \\
\hline
\end{tabular}

Table- 4 shows the results for the question 'In physical education I feel more motivated to practice individual sports because'. In paragraphs c), d) and f), the students all share the same opinion. In point c), all students agreed with the statement that they practice an individual sport outside the school context, which is a reason to feel more motivated to also practice it in physical education. In paragraph d) they agreed with the statement that they obtain better learning, and in paragraph f) all students disagreed with thar statement that they felt better than their colleagues. Different responses were given for the remaining paragraphs.

Table-4: Values of relative and absolute frequencies for the statements of why the students feel more motivated to practice individual sports

\begin{tabular}{|l|l|l|l|}
\hline & I agree & I am in doubt & I disagree \\
\hline a) I like to depend only on myself & $2(66.7 \%)$ & $1(33.4 \%)$ & $0(0 \%)$ \\
\hline b) It has a positive influence on my grades & $2(66.7 \%)$ & $1(33.4 \%)$ & $0(0 \%)$ \\
\hline c) I practice or practiced individual sports outside the school context & $3(100 \%)$ & $0(0 \%)$ & $0(0 \%)$ \\
\hline d) I get better learning & $3(100 \%)$ & $0(0 \%)$ & $0(0 \%)$ \\
\hline e) I feel healthier & $1(33.4 \%)$ & $2(66.7 \%)$ & $0(0 \%)$ \\
\hline f) I feel that I am better than my colleagues & $0(0 \%)$ & $0(0 \%)$ & $3(100 \%)$ \\
\hline
\end{tabular}

Based on the results shown in Table-5, regarding the statement 'In physical education I feel more motivated to practice collective modalities because' the greatest number of 'I agree' responses was for 'I like to play sports in which I play as a team', and the greatest number of 'I disagree' responses was for 'I feel that I am better than my colleagues'.

\section{Table-5: Values of relative and absolute frequencies for the statements of why the students feel more motivated} for the practice of team sports

\begin{tabular}{|l|l|l|l|}
\hline & I agree & I am in doubt & I disagree \\
\hline a) I like to play sports in which I play as a team & $43(89.9 \%)$ & $3(6.3 \%)$ & $2(4.2 \%)$ \\
\hline b) It has a positive influence on my grades. & $23(47.9 \%)$ & $17(35.4 \%)$ & $8(16.7 \%)$ \\
\hline c) I practice or practiced team sports outside the school context. & $38(79.2 \%)$ & $7(14.6 \%)$ & $2(4.2 \%)$ \\
\hline d) I get better learning. & $21(43.8 \%)$ & $17(35.4 \%)$ & $10(28.8 \%)$ \\
\hline e) I feel healthier. & $30(62.5 \%)$ & $13(27.1 \%)$ & $5(10.4 \%)$ \\
\hline f) I feel that I am better than my colleagues & $10(20.8 \%)$ & $10(20.8 \%)$ & $28(58.3 \%)$ \\
\hline
\end{tabular}

Table-6 shows the modalities that students felt most motivated to practice in physical education, according to their responses in the questionnaire. In this regard, it was observed that football was the sport that students were most motivated to practice in physical education, with 17 responses, all male, whereas gymnastics was the sport with the fewest responses.

Table-6: Absolute frequency values of the answers regarding the sports that students feel most motivated to practice in physical education classes

\begin{tabular}{|l|l|l|}
\hline & Female & Male \\
\hline Football & 0 & 17 \\
\hline Futsal & 1 & 3 \\
\hline Volleyball & 8 & 2 \\
\hline Basketball & 5 & 10 \\
\hline Tennis & 0 & 2 \\
\hline Gymnastics & 1 & 0 \\
\hline
\end{tabular}

As it was not possible to compare 'sex' and 'type of education' in relation to question 3, given that the sample consisted of only 3 students, only the comparison with question 4 was made, and the results are shown in Table-7. In fact, statistically significant differences were found between the two sexes with a p- 
Ricardo Ferraz et al., J Adv Sport Phys Edu, Apr, 2021; 4(4): 51-58

value of 0.255 . Females disagreed more, whereas the males' responses were distributed across 'I agree' and 'I am in doubt'. In the comparison between education, there are statistically significant differences in point d) with a p-value of 0.435 , with the professional education class agreeing more, whereas the responses of the regular education class are distributed across 'Disagree' and 'I'm in doubt'.

Table-7: Values of Fisher's Exact Test and Cramer's $V$ for the relationship between gender and education in the question 'In physical education I feel more motivated to practice team sports because:'

\begin{tabular}{|l|l|l|l|l|}
\hline & \multicolumn{2}{|l|}{ Gender } & \multicolumn{2}{l|}{ Type of Education } \\
\hline & $\begin{array}{l}\text { Exact Fisher p- } \\
\text { value }\end{array}$ & $\begin{array}{l}\text { Cramer V } \\
\text { Exact Fisher p- } \\
\text { value }\end{array}$ & $\begin{array}{l}\text { Cramer } \\
\text { V }\end{array}$ \\
\hline a) I like to play sports in which I play as a team & 0.585 & 0.184 & 0.505 & 0.211 \\
\hline b) It has a positive influence on my grades. & 1.000 & 0.114 & 0.320 & 0.303 \\
\hline $\begin{array}{l}\text { c) I practice or practiced team sports outside the } \\
\text { school context. }\end{array}$ & 0.256 & 0.256 & 0.003 & 0.466 \\
\hline d) I get better learning. & 0.161 & 0.294 & 0.435 & 0.257 \\
\hline e) I feel healthier. & 0.577 & 0.207 & 1.000 & 0.087 \\
\hline f) I feel that I am better than my colleagues & 0.255 & 0.397 & 0.120 & 0.336 \\
\hline
\end{tabular}

Table- 8 shows that females disagreed more with the statement 'I feel that I am better than my colleagues', with 14 choosing 'I disagree' and only 1 response to 'I agree'. Meanwhile, Table-9 shows that more professional students agreed with the statement 'I practiced or practiced team sports outside the school context' than regular students, with 20 choosing 'I agree', 2 'I disagree' and 4 'I am in doubt'.

Table-8: Values of relative and absolute frequencies for the answers to the item 'I feel that I am better than my colleagues' in question 4 of the questionnaire

\begin{tabular}{|l|l|l|l|l|}
\hline \multicolumn{2}{|c|}{} & \multicolumn{2}{|l|}{ Gender } & \multirow{2}{*}{ Total } \\
\cline { 2 - 5 } \multicolumn{2}{|c|}{} & Female & Male & \\
\hline I feel that I am better than my colleagues. & I agree & 1 & 12 & 13 \\
\cline { 2 - 5 } & I disagree & 14 & 14 & 28 \\
\cline { 2 - 5 } & I'm in doubt & 0 & 10 & 10 \\
\hline
\end{tabular}

Table-9: Values of relative and absolute frequencies of the answers to the item 'I practiced or practiced team sports outside the school context' of question 4 of the questionnaire

\begin{tabular}{|l|l|l|l|l|}
\hline \multirow{2}{*}{\multicolumn{2}{|c|}{}} & \multicolumn{2}{|c|}{ Type of Education } & \multirow{2}{*}{ Total } \\
\cline { 2 - 5 } \multicolumn{2}{|c|}{} & Professional & Regular & \\
\hline I practice or practiced team sports outside the school context & I agree & 20 & 3 & 23 \\
\cline { 2 - 5 } & I disagree & 2 & 8 & 10 \\
\cline { 2 - 5 } & I'm in doubt & 4 & 13 & 17 \\
\hline
\end{tabular}

\section{DISCUSSION}

The main objective of this study was to analyse whether students felt more motivated to practice individual or team sports in physical education classes, and their reasons for these motivations. In general, and according to the results given above, it is evident that a greater number of students stated that they felt more motivated to practice team sports (i.e., 48 students) than individual sports (i.e., 3 students). The main reason given for this was the fact that they like to play sports as a team. When comparing gender, only 2 male and 1 female students preferred individual sports. Finally, regarding the differences between the type of education, it was found that only 2 students of regular education and 1 student of professional education felt more motivated to practice individual sports.

Based on the results shown in Table-1, only 3 students were more motivated to practice individual sports in physical education, whereas the remaining 48 students showed a greater motivation to practice team sports. These results are in line with previous studies [29-31] which have found that male and female students had a more favourable opinion on the practice of team sports. Based on this prior research $[32,33]$ it was found that both the preferences of students and those of teachers were for team sports, because the vast majority of students felt more motivated to practice football, the sport most practiced in physical education. These results may be due to the fact that team sports are more socialized, which may justify the answers given in tables 4 and 5, whereby it was found that students liked sports that were played as a team. In fact, according to a previously investigation [34], socialization is one of the main stimuli for the practice of physical activities among young people. Another potential reason for students to feel more motivated to practice team sports is the fact that football is a team sport, and as the most practiced sport in the world, a large majority of students 
Ricardo Ferraz et al., J Adv Sport Phys Edu, Apr, 2021; 4(4): 51-58

in all schools, regardless of the type of education feel more motivated to play it.

The analysis of the data in table 2 indicates that there were more students in regular education who did not practice any modality inside or outside the school context and more students in professional education practicing sports, with a greater incidence in males and in the practice of team sports. In fact, similarities are found here with a previous investigation [35], who found that boys played more sports, specifically team sports and especially football. A possible justification for the existence of more students of professional education who practice a modality inside or outside the school context may be related to the fact that the class and professional education in question belong specifically to professional education in sport. Regarding the fact that more male students play sports and mostly collective ones, this may be due to the fact that there is a greater opportunity inside and outside the school for the practice of team sports and also greater male interest in the practice of these sports. In fact, the present results seem to support selfdetermination theory with regard to the positive and adaptive effects of intrinsic motivation and this is in line with previous reports [36]. In addition, there are also autonomous forms of extrinsic motivation that can have a positive influence on an athlete's cognitions, behaviour patterns and emotions. Which is in line with some previous empirical reports, which suggested that high levels of autonomous and controlled motivation may be positively linked to indicators such as pleasure and satisfaction [37], performance [38], pleasure and activity in physical education classes [39] and perceptions of autonomy, competence and relationship, as well as effort, value and pleasure [40].

Through the answers outlined in Table-3, it appears that in addition to the students who already practiced a collective sport outside the school environment, the students who did not practice any sport preferred the team sports in class. In addition, with regard to the 8 students who practiced an individual sport, 5 of them felt more motivated at school for the practice of team sports. In this case, the results obtained appear counterintuitive and not to follow the pattern of other choices. This is because, on the one hand, the totality of students who practiced team sports outside the school context also preferred to practice them in physical education, whereas in the case of students who preferred individual sports, more than $50 \%$ preferred team sports in physical education classes.

Regarding the results found for the question 'In physical education, I feel more motivated to practice individual sports because', 3 respondents were in agreement with the items of paragraphs c), d) and f). With regard to students who were more motivated to practice team sports, this may be because of the answers given for point a) 'I like to play sports in which we play as a team', for which $89.9 \%$ of respondents selected 'I agree'. These data are in line with the similar study [41], in which $80.5 \%$ chose 'I like to work in a team' as the reason for the practice of sports, and $87.6 \%$ chose 'I like team spirit 'with $87.6 \%$. In addition, students felt more motivated when they practiced team sports because there was more socialisation and teamwork [42].

The data presented in table 6 in response to the question "Which sport are you most motivated to practice in physical education?" show that football, volleyball and basketball were the modalities with the highest number of responses, with volleyball being the most chosen modality for women and football for men. These results are in line with what has been reported previously [31, 32]. In fact, students prefer these particular sports, because normally these are the ones approached over the years in physical education [43].

Based on the analysis in Table-7 and derived from the fact that there was a strong association, $\mathrm{p} \geq$ 0.5 , it is observed that in the item 'I feel that I am better than my colleagues' there was a statistically significant difference in relation to the gender variable, whereby the females disagreed more. These results indicate that girls did not consider this item as one of the reasons why they felt more motivated for team sports. In addition, they considered that boys had superior performances in physical education classes, which corroborates what has been previously reported [44].

In relation to the results presented in table 9, for the variable 'Teaching', there was a statistically significant difference in the number of 'I agree' responses, with more professional education students answering that they practice team sports outside the school context, this being a reason for them to feel more motivated to also practice team sports in physical education classes. As mentioned above, one of the explanations for this result may be that due to the fact that the group that attends professional education, belongs specifically to a specific sport course, which is why there is a greater pleasure in sports. That is, there is a greater intrinsic motivation to perform the task, which is directly linked to personal satisfaction, which appears as a challenge that students feel in the face of the tasks assigned to them [45]. In fact, with regard to the motivational determinants of pleasure and interest, physical education presents itself as an effective means for personal well-being, as it involves a motivation that favours self-improvement and continuous personal benefit $[46,47]$.

\section{CONCLUSION}

This study aimed to establish the motivations that lead students to prefer the practice of team sports or sports during physical education classes. The results indicate that students, regardless of the type of education they attend and their gender, prefer the 
Ricardo Ferraz et al., J Adv Sport Phys Edu, Apr, 2021; 4(4): 51-58

practice of team sports. Based on our results this may be due mainly to the fact that they like to play sports as a team, essentially due to the fact that they like to play sports played as a team and, consequently, because they play these sports outside the school context, in addition to the apparent predominance in the teaching of team sports in physical education classes. This study had some limitations, which prevented a wider coverage of the results and analysis of the study. One of the main limitations was the fact that the small sample and within it there are a greater number of boys in relation to girls, and it would be preferable to have an equal or close number of female and male pupils for an equitable analysis between genders. This information can be useful for teachers to try to approach, during physical education classes, individual sports with the same frequency, with which they approach team sports. In fact, this change can lead to an increase in the taste for individual modalities, which can contribute to greater motivation on the part of students who prefer this type of modality in relation to team sport modalities.

Conflict of Interest: Authors declare that they have no conflict of interest.

\section{ACKNOWLEDGEMENTS}

This work is supported by national funding through the Portuguese Foundation for Science and Technology, I.P., under project UID04045/2020.

\section{REFERENCES}

1. Quennerstedt, M., \& Larsson, H. (2015). Learning movement cultures in physical education practice. Sport, Education and Society, 20(5), 565-572.

2. Bailey, R. (2006). Physical education and sport in schools: A review of benefits and outcomes. Journal of School Health, 76(8), 397-401.

3. Cooper, B. S., \& Mulvey, J. D. (2012). Intersections of children's health, education, and welfare. Palgrave Macmillan.

4. Landry, B. W., \& Driscoll, S. W. (2012). Physical activity in children and adolescents. PM\&R, 4(11), 826-832.

5. Janssen, I., \& LeBlanc, A. G. (2010). Systematic review of the health benefits of physical activity and fitness in school-aged children and youth. International Journal of Behavioral Nutrition and Physical Activity.

6. Loprinzi, P. D., Cardinal, B. J., Loprinzi, K. L., \& Lee, H. (2012). Benefits and environmental determinants of physical activity in children and adolescents. Obesity Facts, 5(4), 597-610.

7. Bailey, R., Armour, K., Kirk, D., Jess, M., Pickup, I., \& Sandford, R. (2009). The educational benefits claimed for physical education and school sport: An academic review. Research Papers in Education, 24(1), 1-27.

8. McKenzie, T. L. (2007). The preparation of physical educators: A public health perspective.

Quest, 59(4), 345-357.

9. Ferraz, R., Branquinho, L., Coelho, P., \& Marinho, D. A. (2020). Effects of a Training Program on Physical Fitness and Specific Motor Skills in the Elementary School. International Journal of Orthopedics and Sports Medicine (IJOSM), 1-6.

10. Bryan, C. L., \& Solmon, M. A. (2012). Student motivation in physical education and engagement in physical activity. Journal of sport behavior, 35(3).

11. de Araújo, S., Mesquita, T., Araújo, A., \& de Bastos, A. (2008). Motivação nas aulas de educação física: um estudo comparativo entre gêneros. EFDeportes. com. Revista Digital. Buenos Aires, ano, 13.

12. Self-Determination Theory: Basic Psychological Needs in Motivation, Development, and Wellness. (2017). Self-Determination Theory: Basic Psychological Needs in Motivation, Development, and Wellness.

13. Ryan, R. M., \& Deci, E. L. (2000). Selfdetermination theory and the facilitation of intrinsic motivation, social development, and wellbeing. American Psychologist, 55(1), 68-78.

14. Fernandez-Rio, J., de las Heras, E., González, T., Trillo, V., \& Palomares, J. (2020). Gamification and physical education. Viability and preliminary views from students and teachers. Physical Education and Sport Pedagogy, 25(5), 509-524.

15. Veiga, F. H., Festas, M., Taveira, M. do C., Galvão, D., Janeiro, I., Conboy, J., ... Pereira, T. (2012). Envolvimento dos alunos na escola: conceito e relação com o desempenho académico - sua importância na formação de professores. Revista portuguesa de pedagogia, 3147.

16. Kusurkar, R. A., Ten Cate, T. J., Vos, C. M. P., Westers, P., \& Croiset, G. (2013). How motivation affects academic performance: a structural equation modelling analysis. Advances in health sciences education, 18(1), 57-69.

17. Marques, A., Gómez, F., Martins, J., Catunda, R., \& Sarmento, H. (2017). Association between physical education, school-based physical activity, and academic performance: a systematic review. Retos, 31(31), 316-320.

18. Tresca, R. P., \& De Rose Jr, D. (2008). Estudo comparativo da motivação intrínseca em escolares praticantes e não praticantes de dança. Revista Brasileira de Ciência e Movimento, 8(1), 9-14.

19. Deci, E. L., \& Ryan, R. M. (2010). Intrinsic motivation. The corsini encyclopedia of psychology, 1-2.

20. Samulski, D., \& Noce, F. (2002). Perfil psicológico de atletas paraolímpicos brasileiros. Revista Brasileira de Medicina do esporte, 8(4), 157-166.

21. Berleze, A., Vieira, L. F., \& Krebs, R. J. (2002). Motivos que levam crianças à prática de 
Ricardo Ferraz et al., J Adv Sport Phys Edu, Apr, 2021; 4(4): 51-58

atividades motoras na escola. Journal of Physical Education, 13(1), 99-107.

22. Woolfolk, R. (2000). Cognition and emotion in counseling and psychotherapy. Practical Philosophy, 3(3), 19-27.

23. Silva, M., Dorso, E., Azhar, A., \& Renk, K. (2007). The relationship among parenting styles experienced during childhood, anxiety, motivation, and academic success in college students. Journal of College Student Retention: Research, Theory \& Practice, 9(2), 149-167.

24. Sarmento, H., Catita, L., \& Fonseca, A. (2008). Sport motivation-A comparison between adult football players competing at different levels. In 5th International Scientific Conference on Kinesiology.

25. Schwaab, D. R. (2014). Motivação intrínseca e extrínseca nas aulas de educação física.

26. de Almeida, P. C., \& Cauduro, M. T. (2007). O desinteresse pela Educação Física no ensino médio. Lecturas: Educación física y deportes, (106), 59.

27. Meira, M. N., Leal, W. V. S., \& Ferreira, C. R. (2018). Motivação de professores e alunos nas aulas de educação física em uma escola pública da cidade de Montes Claros-MG. Revista Bionorte, 7(1).

28. Cohen, J. (2013). Statistical Power Analysis for the Behavioral Sciences. Statistical Power Analysis for the Behavioral Sciences. Academic press.

29. Luke, M. D., \& Sinclair, G. D. (1991). Gender differences in adolescents' attitudes toward school physical education. Journal of Teaching in physical Education, 11(1), 31-46.

30. Gonçalves, C. A. (2017). Avaliação do processo de ensino-aprendizagem em Educação Física. Boletim Sociedade Portuguesa de Educação Física, (10-11), 111-134.

31. Koca, C. (2009). Gender interaction in coed physical education: a study in Turkey. Adolescence, 44(173).

32. Hill, G., \& Cleven, B. (2005). A comparison of 9th grade male and female physical education activities preferences and support for coeducational groupings. The Physical Educator, 62(4).

33. Pacheco, C. (2008). A Educação Física no Ensino Básico: Contributos para a Mudança. Universidade dos Açores: Departamento De Ciências da Educação.

34. Vieira, V. C. R., Priore, S. E., \& Fisberg, M. (2002). A atividade física na adolescência. Adolesc Latinoam, 3(1), 0.

35. Serrano, J., França, P., \& Grosso, F. (2000). A influência da variável sexo nas actividades físicas das crianças do meio urbano. Revista do Departamento de Educação Física e Artística, 59-
66.

36. Wegner, M., \& Teubel, T. (2014). The implicit achievement motive predicts match performances and the explicit motive predicts choices for target distances in team sports. International Journal of Sport Psychology, 45(6), 621-638.

37. Vlachopoulos, S. P., \& Karageorghis, C. I. (2005). Interaction of external, introjected, and identified regulation with intrinsic motivation in exercise: Relationships with exercise enjoyment. Journal of Applied Biobehavioral Research, 10(2), 113-132.

38. Gillet, N., Vallerand, R., \& Rosnet, E. (2009). Motivational clusters and performance in a reallife setting. Motivation and Emotion, 33, 49-62.

39. Yli-Piipari, S., Watt, A., Jaakkola, T., Liukkonen, J., \& Nurmi, J.-E. (2009). Relationships between physical education students' motivational profiles, enjoyment, state anxiety, and self-reported physical activity. Journal of sports science \& medicine, 8(3), 327-336.

40. Ullrich-French, S., \& Smith, A. L. (2009). Social and motivational predictors of continued youth sport participation. Psychology of Sport and Exercise, 10(1), 87-95.

41. Matos, Maria de Fátima \& Cruz, J. F. A. (1997). Desporto escolar - motivação para a prática e razões para o abandono. Teoria, investigação e prática, 2(3), 459-489.

42. Perlman, D., \& Goc Karp, G. (2010). A selfdetermined perspective of the sport education model. Physical Education and Sport Pedagogy, 15(4), 401-418.

43. Woodson-Smith, A., Dorwart, C. E., \& Linder, A. (2015). Attitudes toward physical education of female high school students. Physical Educator, 72(3), 460.

44. Azzarito, L., \& Solomon, M. A. (2005). A reconceptualization of physical education: The intersection of gender/race/social class. Sport, Education and Society, 10(1), 25-47.

45. Xiang, P., Ağbuğa, B., Liu, J., \& McBride, R. E. (2017). Relatedness need satisfaction, intrinsic motivation, and engagement in secondary school physical education. Journal of Teaching in Physical Education, 36(3), 340-352.

46. González Valero, G., Zurita Ortega, F., \& Martínez Martínez, A. (2017). Panorama motivacional y de actividad física en estudiantes: una revisión sistemática. Education, Sport, Health and Physical Activity (ESHPA), 1(1), 41-58. Retrieved from http://hdl.handle.net/10481/48961

47. González-Valero, G., Ubago-Jiménez, J. L., Ramírez-Granizo, I. A., \& Puertas-Molero, P. (2019). Association between motivational climate, adherence to mediterranean diet, and levels of physical activity in physical education students. Behavioral Sciences, 9(4), 37. 